\title{
Implementasi Kebijakan Penyusunan Daftar Pemilih di Kabupaten Enrekang
}

\author{
ISyamsinar, ${ }^{2}$ Andi Ifdal, 3 Muhammad Rais Rahmat, 4 Muhammad Rohady \\ Ilmu Administrasi Negara, Program Pascasarjana,STISIP Muhammadiyah Rappang \\ Enrekang, Sindenreng Rappang, Indonesia \\ 'inarsyam@gmail.com, ${ }^{2}$ andiifdall@gmail.com, ${ }^{3}$ mraisrahmat@yahoo.com,
}

\begin{abstract}
Abstrak -- Tujuan penelitian untuk: Menganalisis implementasi kebijakan penyusuan daftar pemilih pada pemilu tahun 2014 di Kabupaten Enrekang; Menganalisis faktor-faktor determinan yang mendukung dan menghambat implementasi kebijakan penyusunan daftar pemilu tahun 2014 di Kabupaten Enrekang; dan Menganalisis dampak penyusunan daftar pemilu tahun 2014 di Kabupaten Enrekang.Metode penelitian: Kualitatif semu dengan menggunakan deskriptif tabel frekeunsi dan kualitatif deskriptif. Sedangkan teknik analisis data yang digunakan adalah model interaktif dan triangulasi untuk keabsahan data. (I) Hasil analisis deskriptif tabel frekuensi: penerapan implemtentasi kebijakan dengan indikator: komunikasi, sumber daya, sikap aparatur birokrasi, dan struktur birokrasi dalam konteks penyusunan daftar pemilih nilai persentase secara kumulatif 87,78\%; (2) Hasil analisis kualitatif deskriptif: KPU telah melaksanakan penyusunan daftar pemilih secara proporsional, efektif, dan rasional.Faktor-faktor determinan, faktor pendukung adalah Kepemimpinan dan motivasi; dan faktor penghambat adalah partisipasi masyarakat.Adapun dampak penyusunan daftar pemilih pada Pemilu Tahun 2014 di Kabupaten Enrekang, yaitu: Pelembagaan nilai-nilai demokrasi, dan penguatan proses pendidikan politik rakyat.
\end{abstract}

Keywords: Implementation, Policy, List of voters, and General election

\section{PENDAHULUAN}

Undang-Undang Nomor 8 Tahun 2012 sebagaimana diatur dalam Pasal 19 menyatakan bahwa : "Warga Negara Republik Indonesia yang pada hari pemungutan suara pemilihan Anggota Dewan Perwakilan Rakyat, Dewan Perwakilan Daerah dan Dewan Perwakilan Rakyat Daerah sudah berumur 17 (tujuh belas) tahun atau sudah/pernah kawin mempunyai hak memilih". Untuk dapat menggunakan hak memilih dalam pemilihan Warga Negara Republik Indonesia harus terdaftar sebagai pemilihdengansyaratsyarat yang harus dipenuhi: (a) tidak terganggu jiwa/ingatannya; (b) tidak sedang dicabut hak pilihnya berdasarkan putusan pengadilan; dan (c) berdomisili di daerah pemilihan sekurang-kurangnya 6 (enam) bulan sebelum disahkannya daftar pemilih sementara yang dibuktikan dengan Kartu Tanda Penduduk. Jumlah pemilih berdasarkan data padapenyelenggaraanPemilu di KabupatenEnrekang, yaitu: (a) Pemilihan Gubernur dan Wakil Gubernur Provinsi Sulawesi Selatan Tahun
2013 sebanyak I42.678 wajibpilih; (b) Pemilihan Umum Anggota Dewan Perwakilan Rakyat, Dewan Perwakilan Daerah dan Dewan Perwakilan Rakyat DaerahTahun 20I3, sebanyak I49.422 wajib pilih; dan (c) Pemilihan Umum Presiden dan Wakil Presiden Tahun 2014 sebanyak I5I.033 wajib pilih.

Peranan KPU dalam memutakhirkan data pemilih sebagaimana diatur dalam Undang-Undang Republik Indonesia Nomor 15 tahun 201I tentang Penyelenggara Pemilihan Umum pada pasal 10 ayat (I) huruf $f$ yang berbunyi, bahwa "memutakhirkan data pemilih berdasarkan data kependudukan yang disiapkan dan diserahkan oleh pemerintah dengan memperhatikan data pemilu dan/atau pemilihan gubernur, bupati, walikota terakhir dan menetapkannya sebagai daftar pemilih". Undang-Undang Republik Indonesia Nomor 15 tahun $201 \mathrm{I}$ tentang Penyelenggara Pemilihan Umum pada pasal II 9 ayat (I) untuk penyelenggaraan Pemilu, KPU membentuk peraturan KPU dan keputusan KPU. Sementara itu, dalam ayat (2) Peraturan KPU sebagaimana dimaksud pada ayat (I) merupakan pelaksanaan peraturan perundang-undangan, sehingga KPU membentuk Peraturan Komisi Pemilihan Umum Nomor 9 Tahun 2013 tentang Penyusunan Daftar Pemilih untuk Pemilihan Umum Anggota Dewan Perwakilan Rakyat, Dewan Perwakilan Daerah dan Dewan Perwakilan Rakyat Daerah.

Menurut Edward III (1980) dalam Firmansyah (2003), terdapat empat faktor atau variabel kritis dalam implementasi kebijakan publik, sebagai berikut :

a. Faktor Komunikasi, Komunikasi yaitu meliputi penyampaian informasi, kejelasan informasi dan konsistensinya.

b. Faktor Sumberdaya, Sumberdaya dimana untuk efektifnya implementasi diperlukan sumberdaya yang cukup. Sumberdaya yang penting meliputi staf yang tersedia dalam jumlah dan keahlian yang memadai, informasi, kewenangan dan fasilitas yang mendukung.Sumberdaya yang penting dalam proses implementasi adalah mencakup staf/tenaga kerja yang mempunyai keahlian dan kemampuan melaksanakan tugas,

c. Faktor Disposisi, yaitu sikap dan komitmen dari para pelaksana program (birokrat), dimana mereka harus memiliki keinginan untuk melaksanakannya. Merupakan sikap dan komitmen dari para pelaksana, yang diartikan sebagai kecenderungan, keinginan, atau kesepakatan para pelaksana untuk melaksanakan kebijakan/program. Sikap yang 
mempengaruhi keberhasilan pelaksanaan suatu kebijakan/program adalah semangat,

d. Faktor Struktur Birokrasi, yaitu standar operasional yang mengatur tata kerja dan tata laksana.

Implementasi kebijakan merupakan suatu bentuk hubungan yang dapat memungkinkan tercapainya tujuan dan sasaran dalam kebijakan publik, sehingga dapat terwujud hasil akhir dari kegiatan yang dilaksanakan pemerintah. Dalam prakteknya implementasi kebijakan merupakan suatu proses yang begitu kompleks bahkan tidak jarang bermuatan politis dengan adanya intervensi berbagai kepentingan.

Peraturan Komisi Pemilihan Umum Nomor 09 Tahun 2013 Tentang Penyusunan Daftar Pemilih untuk Pemilihan Umum Anggota Dewan Perwakilan Rakyat, Dewan Perwakilan Daerah dan Dewan Perwakilan Rakyat Daerah akan dapat berjalan efektif, harus memiliki enam kriteria sebagaimana dijelaskan oleh Nugroho (2007:24) sebagai berikut, yaitu: (I) Efektivitas, berkenaan dengan apakah suatu alternatif mencapai hasil yang diharapkan; (2) Efisiensi, berkenan dengan jumlah usaha yang diperlukan untuk menghasilkan tingkat efektivitas yang dikehendaki; (3) Kecukupan, berkenaan dengan seberapa jauh suatu tingkat efektivitas memuaskan kebutuhan, nilai atau kesempatan yang menumbuhkan adanya masalah; (4) Perataan (equality), berkenaan dengan pemerataan distribusi manfaat kebijakan; (5) Responsivitas, berkenaan dengan seberapa jauh suatu kebijakan dapat memuaskan kebutuhan, preferensi, atau nilai kelompok-kelompok masyarakat yang menjadi target kebijakan; dan (5) Kelayakan, (appropriateness), berkenaan dengan pertanyaan apakah kebijakan tersebut tepat untuk suatu masyarakat.

Panitia Pemungutan Suara (PPS) merupakan badan pelaksana dari tugas-tugas yang dibebankan kepadanya, berdasarkan Undang-Undang Republik Indonesia Nomor I5 Tahun 20II tentang Penyelenggara Pemilihan Umum. Di samping itu ada juga Peraturan Komisi Pemilihan Umum Nomor 09 Tahun 2013 tentang Penyusunan Daftar Pemilih untuk Pemilihan Umum Anggota Dewan Perwakilan Rakyat, Dewan Perwakilan Daerah dan Dewan Perwakilan Rakyat Daerah yang menjadi dasar Panitia Pemungutan Suara dalam melaksanakan tugasnya.

I. Pencocokan dan Penelitian Daftar Pemilih Sementara. Proses penetapan Data Penduduk Pemilih Potensial Pemilu (DP4) menjadi tugas pemerintah, sedangkan Daftar Pemilih Sementara (DPS) berada di wilayah kewenangan Komisi Pemilihaan Umum. Data Penduduk Pemilih Potensial Pemilu (DP4) berasal dari Pendaftaran Pemilih dan Pendataan Penduduk Berkelanjutan (P4B) yang merupakan konsep awal, agar setiap warga masyarakat dapat terdata, baik sebagai pemilih maupun sebagai penduduk. Pendataan penduduk harus dilakukan secara terus-menerus, sebagai wujud dari penyediaan data yang baik dan akurat secara berkelanjutan.
2. Penyusunan Daftar Pemilih Sementara. Pemutakhiran data dan daftar pemilih berkaitan dengan identitas warga masyarakat menggunakan hak pilihnya dalam pemilu. Hak pilih seorang individu dihargai sebagai kebebasan seseorang untuk menentukan sikapnya dalam memberikan pilihan, karena harus dikelola secara baik sistem pendaftaran pemilih permanen membawa konsekuesi melibatkan banyak pihak, terutama Pemerintah Daerah yang ditangani oleh Dinas Kependudukan dan Catatan Sipil. Tanggungjawab penyediaan data pemilih berada pada lembaga yang bersangkutan, seperti KPU Kabupaten/Kota atau Dinas Kependudukan dan Catatan Sipil.

3. Proses Perbaikan Daftar Pemilih Sementara. Daftar Pemilih Sementara sebagai hasil dari Data Penduduk Pemilih Potensial Pemilu (DP4) yang diterima oleh KPU Kabupaten Enrekang. Tindak lanjut dari Data Penduduk Pemilih Potensial Pemilu menjadi Daftar Pemilih Sementara. Perbedaan antara Daftar Pemilih Sementara (DPS) dan Data Penduduk Pemilih Potensial Pemilu (DP4) tidak mencantumkan nama Tempat Pemungutan Suara (TPS) demikian pula di dalam Daftar Pemilih Sementara (DPS) tidak mencantumkan Tempat Pemungutan Suara (TPS) pada kolom keterangan pada saat penyerahan dari KPU Kabupaten Enrekang kepada Panitia Pemungutan Suara melalui Panitia Pemilihan Kecamatan (PPK).

4. Penyusunan Daftar Pemilih Sementara Hasil Perbaikan. Daftar Pemilih Sementara sebagai hasil dari Data Penduduk Pemilih Potensial Pemilu (DP4) yang diterima oleh KPU Kabupaten Enrekang. Tindak lanjut dari Data Penduduk Pemilih Potensial Pemilu menjadi Daftar Pemilih Sementara. Perbedaan antara Daftar Pemilih Sementara (DPS) dan Data Penduduk Pemilih Potensial Pemilu (DP4) tidak mencantumkan nama Tempat Pemungutan Suara (TPS) demikian pula di dalam Daftar Pemilih Sementara (DPS) tidak mencantumkan Tempat Pemungutan Suara (TPS) pada kolom keterangan pada saat penyerahan dari KPU Kabupaten Enrekang kepada Panitia Pemungutan Suara melalui Panitia Pemilihan Kecamatan (PPK).

5. Pemutakhiran Daftar Pemilih Tetap. Pengelolaan data dan daftar pemilih dimungkinkan memegang prinsip yang benar berdasarkan aturan-aturan yang berlaku. Aturan yang dibuat menjadi pedoman dasar dalam mengelola data dan daftar pemilih berdasarkan pertimbangan teknis. Prinsip pemeliharaan daftar pemilih agar tidak menimbulkan masalah utama dengan mempertimbangkan status daftar pemilih. Draft dan aturan yang dibuat mengedepankan data dan daftar pemilih yang mencakup nama, tempat dan tanggal lahir, alamat, tanggal pendataan, kewarganegaraan. Data yang relevan tentang kapasitas pemilih, apabila pemilih memilik dua atau lebih alamat, harus menentukan tempat tinggal yang mana yang digunakan sebagai elektoral mereka. 


\section{METODE PENELITIAN}

Jenis Penelitian yang dilakukan untuk mengolah dan menganalisis penelitian ini adalah penelitian metode deskriptif kuantitatif.Populasi dan informan mencakup seluruh personel yang terlibat dalam penyelenggaraan penyusunan daftar pemilih pada pemilihan umum tahun 2014 di Kabupaten Enrekang.Adapun tekhnik penarikan sampel yang digunakan dengan tingkat kesalahan $10 \%$, jadi jumlah sampel yang digunakan adalah 112 orang, sedangkan informan sebanyak 4 orang.Adapun tekhnik pengumpulan data yaitu wawancara, observasi, dan studi kepustakaan.Sedangkan tekhnik analisis data yaitu analisis data reduksi data, sajian data, dan penarikan kesimpulan

\section{HASIL DAN PEMBAHASAN}

Pemutakhiran (perbaikan dan penambahan) yang dilakukan untuk melakukan penyempurnaan terhadap DPS yang ada. Adapun kegiatan pemutakhiran (up daiting) meliputi perbaikan terhadap seluruh identitas data dan daftar pemilih, termasuk nama, tempat tanggal lahir, umur, jenis kelamin dan alamat calon pemilih, serta penetapan TPS. Perbaikan data pemilih dan identitas lainnya diikuti dengan penambahan pemilih baru dan pemilih tambahan dalam DPS. Pemilih baru adalah pemilih yang sudah memasuki usia memilih akan tetapi tidak terdaftar sebagai pemilih, sedangkan pemilih tambahan adalah pemilih yang tidak terdaftar dalam Pemilu sebelumnya. Setelah pemutkairan dilakukan, maka tahap selanjutnya adalah melakukan pengumuman kembali terhadap DPS yang sudah diperbaiki. Pengumuman pada tahap pertama berkaitan dengan pemgumuman DPS yang baru diterima dari KPU Kabupeten Enrekang melalui PPK Kecamatan Cendana. DPS yang diterima sebelumnya adalah hasil DP4 yang diterima KPU dari Pemerintah Kabupaten Enrekang untuk dimutakhirkan. Proses pengumuman dilakukan agar masyarakat luas dapat memberikan masukan terhadap DPS sebelum ditetapkan menjadi Daftar Pemilih Tetap (fixed voters). Setelah daftar pemilih sementara diumumkan kepada masyarakat luas, agar masyarakat calon pemilih mengetahui tentang dirinya, sudah terdaftar atau belum terdaftar.

Pengumuman setelah dilakukan pemutakhiran, maka tahap selanjutnya adalah penetapan DPSHP Akhir yang sudah diumumkan menjadi DPT. Penetapan dilakukan setelah pengumuman dan Daftar Pemilih Sementara Hasil Perbaikan Akhir dilakukan, maka PPS menetapkan DPT melalui rapat pleno tebuka untuk menetapkan jumlah pemilih di wilayah kerja PPS masing-masing. Penetapan dilakukan berkaitan dengan keseluruhan jumlah pemilih dan jumlah pemilih berdasarkan jenis kelamin. Daftar Pemilih Hasil Perbaikan berasal dari DPS yang diumumkan oleh PPS kepada masyarakat dari berbagai masukan, tanggapan, dan saran dari masyarakat dan peserta Pemilu sebagai calon pemilih. Kekeliruan yang terjadi biasanya berkaitan dengan penulisan nama lengkap, tempat/tanggal lahir (umur), status perkawinan, jenis kelamin, alamat tempat tinggal dan jenis cacat yang disandang dinyatakan keliru. Dari identitas calon pemilih yang keliru tersebut, maka perlu diperbaiki dalam formulir Model A.2-KPU (Daftar Pemilih Sementara Hasil Perbaikan).

Tanggapan yang disampaikan oleh warga masyarakat kepada PPS merupakan wujud partisipasi masyarakat dalam sistem retroaktif. Warga masyarakat diminta secara aktif berperan untuk terlibat secara langsung dalam rangka memperbaiki DPS, baik yang sudah terdata sebagai calon pemilih, data calon pemilih keliru, maupun yang tidak terdata sebagai pemilih. Kesadaran dari peran aktif warga masyarakat sebagai calon pemilih didukung dengan kegiatan sosialisasi oleh lembaga penyelenggara Pemilu dengan cara yang maksimal melalui berbagai media. Keadaan masyarakat yang heterogen dan kriteria calon pemilih yang bervariasi menyebabkan perilaku calon pemilih ada yang aktif dan ada pula yang pasif. Bagi calon pemilih yang aktif akan berupaya untuk mendaftarkan diri sebagai pemilih, sementara yang pasif tidak terlalu peduli tentang dirinya, apakah terdata atau tidak terdata sebagai calon pemilih. Berdasarkan fenomena tersebut, maka peneliti melakukan wawancara dengan anggota PPS Pinang An. Munawir, terkait dengan jumlah calon pemilih yang berada diwilayahnya dengan membandingkan antara calon pemilih dengan Kartu Keluarga,bahwa:

Sebagian besar pengurus RT mengetahui calon pemilih yang berada di wilayahnya berdasarkan Kartu Keluarga (KK) yang diterima oleh pengurus RT dengan cara membandingkan antara nama calon pemilih dengan Kartu Keluarga (KK). Warga masyarakat yang tidak terdaftar sebagai pemilih ada yang ditambahkan dan ada yang belum terdaftar, tetapi tidak berada ditempat dan pindah alamat. Akan tetapi terdaftar sebagai pemilih ditempat tersebut, sementara itu ditempat yang lama yang bersangkutan tidak terdaftar. (Wawancara, 5 November 2016).

Bagi warga masyarakat yang tidak terdata sebagai pemilih, secara administratif hak pilihnya terhapus, karena tidak terdaftar sebagai pemilih secara otomatis tidak dapat menggunakan hak pilihnya. Guna menghindari besarnya jumlah calon pemilih tidak terdaftar sebagai pemilih diharapkan masyarakat secara aktif untuk mendaftarkan diri sebagai pemilih. Berdasarkan hasil wawancara, menunjukkan bahwa PPS yang menyatakan calon pemilih yang tidak terdata dalam Data Penduduk Potensial Pemilih Pemilu (DP4) sebanyak 47,62\% ( 10 orang) atau sekitar 4 PPS. Daftar pemilih yang tersedia diterima oleh PPS dalam bentuk Data Penduduk Potensial Pemilih Pemilu yang terdata sebagai pemilih sebesar $52,38 \%$ (I I orang) atau sekitar 
4 PPS atau setengah dari PPS di wilayah PPK Kecamatan Cendana. Data Penduduk Potensial Pemilih Pemilu berasal dari pemerintah Kabupaten Enrekang yang merupakan sumber dari DPS harus dilakukan pemutakhiran oleh PPS. Pemutakhiran Data Penduduk Potensial Pemilu yang seharusnya dilakukan oleh Pemerintah Kabupaten Enrekang melalui Dinas Catatan Sipil dan Kependudukan menjadi input data untuk menentukan DPS. KPU Kabupaten Enrekang menetapkan DPS berdasarkan Data Penduduk Potensial Pemilih Pemilu yang kemudian disampaikan kepada PPS melalui PPK. Dalam Pemilu Anggota Dewan Perwakilan Rakyat, Dewan Perwakilan Daerah dan Dewan Perwakilan Rakyat Daerah tidak melakukan pendataan pemilih, tetapi menggunakan data pemilih dari database DP4. Ternyata DP4 yang disampaikan kepada KPU Kabupaten Enrekang datanya tidak akurat dan banyak calon pemilih yang tidak terdata dan pemilih ganda. Berdasarkan hasil penelitian menunjukkan, bahwa calon pemilih tidak terdata dalam DPS sebanyak 33,33\% atau sekitar 7 PPS calon pemilih tidak terdata. Sementara itu, calon pemilih yang terdata sebagai pemilih mencapai $66,67 \%$ (14 orang) atau sekitar 5 PPS di wilayah PPK Kecamatan Cendana. Keberatan biasanya diajukan oleh masyarakat pada hari dan tanggal pemungutan suara berlangsung, seharusnya respon atau tanggapan masyarakat pada saat diumumkan DPS. Akibatnya masyarakat tidak terdaftar sebagai calon pemilih dan tidak dapat menggunakan hak pilinnya sebagaimana mestinya, meskipun itu merupakan bentuk partisipasi masyarakat peduli dengan hak politiknya namun penyelenggara harus mengikuti ketentuan yang berlaku. Seharusnya bentuk partisipasi masyarakat dapat diajukan pada saat DPS diumumkan dan belum ditetapkan sebagai DPT.

Menurut Haris (1999:15) peran pemilih menjadi sangat menentukan dalam proses dan hasil Pemilu. Ketika pemilih pasif terhadap segala macam informasi tentang Pemilu, maka mobilisasi destruktif dari pihakpihak tertentu dapat terjadi dengan leluasa. Disaat yang sama, ketika pemilih umumnya bersandar pada aspek emosional dalam memformulasikan pilhan politiknya, maka kompetisi yang sehat dalam Pemilu akan berkurang kadar. Oleh karenanya, Pemilu yang Langsung, Umum,engan leluasa. Disaat yang sama, ketika pemilih umumnya bersandar pada aspek emosional dalam memformulasikan pilhan politiknya, maka kompetisi yang sehat dalam Pemilu akan berkurang kadar. Oleh karenanya, Pemilu yang Langsung, Umum, Bebas, Rahasia, Jujur dan Adil akan dapat terwujud jika hadir para pemilih yang aktif dan cerdas. Tipe pemilih seperti ini sangat diperlukan bukan hanya dalam hal membeikan suaranya secara tepat, tetapi ikut serta menjaga proses Pemilu berjalan dengan baik dan benar. Pada dimensi yang sama, peneliti melakukan wawancara dengan Sekretaris KPU Kabupaten Enrekang An. H. Sadeng, S.Pd, MM tentang peran PPS sebagai bagian pelaksanaan Pemilu Anggota DPR, DPD, dan DPRDTahun 2014 adalah menyediakan data pemilih yang akurat sesuai dengan wilayah kerjanya masing-masing, bahwa:

Apabila terjadi kekeliruan daftar pemilih
ataupun orang yang tidak terdaftar sebagai
pemilih, maka ini adalah kewajiban PPS. Ada
tanggapan masyarakat mengenai beberapa
warga masyarakat terdaftar diluar RT domisili
calon pemilih dengan TPS yang jauh dengan
domisili calon pemilih. Akibatnya banyak
warga masyarakat yang tidak menggunakan
hak pilinnya karena jauh dari domisilinya.
Untuk menindak-lanjuti masalah tersebut
dengan dibuat daftar pemilih tambahan pindah
ke alamat yang terdekat, kalau tidak terdaftar
dinyatakan kepada pengurus RT setempat.
(Wawancara,8 Desember 2016).

Penyelesaian masalah daftar pemilih pada saat orang yang seharusnya terdaftar sebagai pemilih, tetapi tidak terdaftar sebagai pemilih menjadi masalah yang krusial dan perlu penanganan serius. Calon pemilih mengajukan keberatan kepada PPS pasca DPS diumumkan, karena dirinya tidak terdaftar sebagai pemilih. Faktor yang paling dominan adalah calon pemilih terdaftar diluar tempat domisilinya atau berada di luar alamat calon pemilih itu berada. Calon pemilih tersebut menyatakan dirinya tidak terdaftar pada TPS domisili calon pemilih. Persoalan calon pemilih yang terdaftar di tempat lain, tetapi tidak terdaftar di TPS domisili calon pemilih dapat diatasi bilamana PPS mengumumkan DPS yang digunakan dalam pemungutan suara diumumkan di tempat-tempat yang dapat dikunjungi oleh calon pemilih. Cara lain yang dapat ditempuh oleh PPS dengan mengumumkan DPT, sehingga calon pemilih dapat mencarai daftar nama yang tertera pada DPT. PPS diberikan batas waktu mengumumkan DPS dengan batas waktu 3 hari sebelum ditetapkan menjadi DPT. PPS diberikan batas waktu mengumumkan DPS dengan batas waktu I4 hari sebelum ditetapkan menjadi DPT. Bagi PPS sebagai pihak yang bertanggungjawab dalam menyediakan daftar pemilih dianggap menjadi persoalan dan sulit untuk ditindak-lanjuti karena daftar pemilih dianggap sudah akurat, karena sudah ditetapkan menjadi DPT. Kesulitan yang dihadapi PPS untuk mencantumkan nama orang yang mendaftarkan diri sebagai pemilih di DPT melanggar ketentuan yang sudah ditetapkan oleh KPU sebagai pembuat kebijakan yang ditempuh oleh PPS mengatasi persoalan tersebut.

Undang-Undang Nomor I5 Tahun 20II tentang Penyelenggara Pemilihan Umum memberikan ruang bagi penyelenggara Pemilihan Umum untuk membuat beberapa peraturan dan keputusan. Pembuatan peraturan merupakan kewenangan KPU yang bersifat mengatur proses seluruh kebijakan yang akan diimplementasikan oleh KPU maupun pelaksana Pemilihan Umum pada tingkat bawah. Pemilihan Umum Anggota DPR, DPD, dan DPRDTahun 2014, KPU membuat Peraturan Komisi Pemilihan Umum Nomor 09 Tahun 2013 tentang Penyusunan Daftar Pemilih 
dalam Pemilihan Umum Anggota DPR, DPD, dan DPRDTahun 20l4. Kebijakan yang dibuat oleh KPU merupakan produk kebijakan yang harus diimplementasikan, karena itu implementasi kebijakan berarti pelaksanaan dan pengendalian arah tindakan kebijakan (Dunn, 1995:80). Tujuan dari kebijakan yang dibuat agar implementator ditingkat teknis mudah melakukan berbagai kegiatan pemutakhiran data pemilih.

Peraturan KPU Nomor 09 Tahun 2013 tentang Penyusunan Daftar Pemilih pada Pemilihan Umum Anggota DPR, DPD, dan DPRDTahun 2014 merupakan suatu kebijakan yang dibuat agar dapat diimplementasikan dan memberikan manfaat pada kontribusi tujuan dari pemutakhiran data pemilih, sebagaimana dijelaskan oleh Winarno (2007:I45) dampak implementasi mempunyai makna bahwa telah ada perubahan yang bisa diukur. Setiap kebijakan diarahkan pada perubahan yang lebih baik dari sebelumnya sebagai parameter untuk melihat efaktivitas dari kebijakan yang dibuat. Implementasi kebijakan tetap diarahkan pada tujuan yang ingin dicapai dari produk kebijakan dalam hal ini pemutakhiran data pemilih. Berdasarkan Peraturan KPU Nomor 09 Tahun 2013 tentang Penyusunan Data Pemilih dalam Pemilihan Umum Anggota DPR, DPD, dan DPRD Tahun 2014 sebagai suatu kebijakan dalam melakukan pemutakhiran data pemilih kebijakan tersebut.

\section{Daftar Pemilih Sementara}

Pemilih yang namanya belum tercantum dalam DPS secara aktif melaporkan kepada PPS di desa/kelurahan melalui pengurus RT/RW atau sebutan lainnya.Warganya yang belum terdaftar atau ada kekeliruan dalam penulisan identitas pemilih dalam DPS dapat memberikan masukan ke PPS.Melakukan perbaikan Daftar Pemilih Sementara berdasarkan masukan masyarakat. Melaporkan kepada PPS pemilih yang belum terdaftar dengan dibantu oleh Pengurus RT/RW mencatat data/nama pemilih baru dalam formulir A.A-KPU(Data Pemilih Baru) dan melakukan perbaikan terhadap identitas pemilih yang keliru berdasarkan masukan yang disampaikan masyarakat ke dalam formulir Model A.2-KPU (Data Pemilih Sementara Hasil Perbaikan).Pencatatan data pemilih baru, meliputi: (I) NIK/Nomor Pemilih; (2) Nama lengkap; (3) Tempat/tanggal lahir; (4) Status perkawinan; (5) Jenis kelamin; (6) Alamat tempat tinggal; dan (7) Jenis cacat yang disandang.Pemilih baru yang sudah didaftar diberikan tanda bukti sudah didaftar yaitu formulir Model A.A-KPU (Formulir tanda bukti sudah didaftar sebagai pemilih baru) dengan ketentuan lembar pertama diserahkan kepada pengurus RT/RW atau sebutan lainnya dan lembar kedua diserahkan kepada pemilih atau anggota keluarga yang mewakili.

Pencatatan perbaikan data pemilih sementara dan pemilih baru dalam Daftar Pemilih Sementara
Hasil Perbaikan dilaksanakan pada tanggal 2 Agustus s/d I5 Agustus 20I3.Pemilih baru dan pemilih yang diperbaiki identitasnya, oleh PPS disalin ke dalam formulir Model A.2.A-KPU (Daftar Pemilih Sementara Hasil Perbaikan).Data pemilih yang identitasnya sudah diperbaiki, oleh PPS dicoret dari Daftar Pemilih Sementara.Daftar Pemilih Sementara Hasil Perbaikan (Formulir Model A.2-KPU) dibuat oleh PPS dalam 3 (Tiga)rangkap dan ditandantangani serta disahkan oleh Anggota PPS dan dibubuhi cap, untuk digunakan: (I) I (satu) rangkap untuk pengumuman; (2) I (satu) rangkap untuk arsip di TPS; (3) I (satu) rangkap untuk dikirim ke KPU Kabupaten/Kota melalui PPK.

Daftar Pemilih Sementara Hasil Perbaikan (Formulir Model A.2-KPU) diumumkan oleh PPS pada tempat yang mudah dilihat atau dijangkau oleh masyarakat dengan bantuan pengurus RT/RW atau sebutan lain untuk mendapatkan tanggapan masyarakat.Jangka waktu pengumuman Daftar Pemilih Sementara Hasil Perbaikan dilaksanakan dari tanggal 17 Agustus s/d 23 Agustus 2013Dalam jangka waktu tersebut diatas, pemilih masih dapat mengajukan usul atau perbaikan penulisan nama dan identitas lainnya. Apabila ada usulan perbaikan, PPS melakukan perbaikan kembali dalam Formulir Model A.2.A-KPU (Perbaikan Daftar Pemilih Sementara Hasil Perbaikan Akhir).

\section{Daftar Pemilih Sementara Hasil Perbaikan}

PPS melakukan perbaikan terhadap DPSHP berdasarkan masukan dan tanggapan dari masyarakat dan peserta Pemilu paling lama I4 (empat belas) hari setelah berakhirnya pengumuman DPSHP. PPS menerima masukan dan tanggapan secara tertulis maupun lisan yang dibukukan dalam satu catatan yang ditandatangani oleh PPS dan pemberi masukan dengan mencantumkan nama masing-masing secara lengkap dan jelas.

Perbaikan DPSHP disusun ke dalam DPSHP akhir (formulir Model A.2.A-KPU). Selanjutnya PPS mengirim DPS (formulir model A.I-KPU), DPSHP (formulir Model A.2-KPU) dan DPSHP Akhir (formulir Model A.2.A-KPU) sebanyak I (satu) rangkap kepada KPU Kabupaten Enrekang melalui PPK digunakan sebagai bahan penyusunan DPT. PPS menyimpan DPS (formulir model A.I-KPU), DPSHP (formulir Model A.2-KPU) dan DPSHP Akhir (formulir Model A.2.A-KPU) sebagai dokumen/arsip.

\section{Penyusunan Daftar Pemilih Tetap (DPT) dan Daftar Pemilih Tambahan}

Daftar Pemilih Sementara (formulir Model A.IKPU) dan Daftar Pemilih Sementara Hasil Perbaikan (formulir Model A.2-KPU) dan DPSHP Akhir (formulir Model A.2.A-KPU) dikirim ke KPU Kabupaten/Kota melalui PPK.KPU Kabupaten/Kota setelah menerima Daftar Pemilih Sementara, 
DPSHP dan DPSHP Akhir dari PPS, kemudian menyalin dalam formulir Model A.3-KPU (Daftar Pemilih Tetap) dan menggandakan sebanyak 2 (dua) rangkap untuk pengumuman berkaitan: (I) I (satu) rangkap untuk pengumuman; (2) I (satu) rangkap untuk arsip di KPPS. Penetapan Daftar Pemilih Tetap paling lambat tanggal 7 September s/d 14 September 2013Setelah Daftar Pemilih Tetap disahkan, KPU Kabupaten/Kota membuat Daftar Pemilih Tetap dalam bentuk hardcopy sebanyak 5 (lima) rangkap untuk digunakan : (I) I (satu) rangkap untuk PPK; (2) 2 (dua) rangkap untuk PPS; (3) 2 (dua) rangkap untuk KPPS.Penyerahan DPT kepada KPU, KPU Provinsi, PPK dan PPS paling lambat tanggal 14 September s/d 20 September 2013.

Daftar Pemilih Tetap diumumkan di PPS/Desa/RT/RW atau tempat lain yang mudah dilihat dan dijangkau oleh masyarakat.Pengumuman Daftar Pemilih Tetap dilaksanakan pada tanggal 21 September 2013 s/d 9 April 2014. Daftar Pemilih Tetap oleh KPU Kabupaten/Kota digunakan untuk: (I) Pemutakhiran Data Pemilih; (2) Pembuatan Kartu Pemilih; (3) Pemda Kabupaten/Kota; (4) KPU sebagai dasar pemutakhiran data pemilih secara berkelanjutan.DPT dapat dilengkapi dengan Daftar Pemilih Tetap Tambahan (DPTB) sampai dengan paling lambat 3 (tiga) hari sebelum hari/tanggal pemungutan suara. DPTB terdiri atas data pemilih yang terdaftar dalam DPT di suatu TPS, tetapi karena keadaan tertentu tidak dapat menggunakan haknya untuk memilih di TPS tempat yang bersangkutan terdaftar.Untuk dapat dimasukkan dalam DPTB seseorang harus menunjukkan bukti identitas diri dan bukti yang bersangkutan telah terdaftar sebagai pemilih dalam DPT di TPS asal. Pemilih, melaporkan kepada PPS asal untuk mendapatkan Surat Pemberitahuan DPTB (Model A.5-KPU) yang akan digunakan hak memilih di TPS lain. PPS berdasarkan laporan pemilih, meneliti apakah pemilih yang bersangkutan terdaftar dalam DPT. Apabila pemilih terdaftar sebagai pemilih dalam DPT, PPS mencatat atau memberikan catatan dalam kolom keterangan pada DPTB (Model A.4KPU) dan memberikan Surat Pemberitahuan DPTB (Model A.5-KPU) dengan ketentuan lembar kesatu untu pemilih yang bersangkutan dan lembar kedua sebagai arsip PPS.

Pemilih tambahan menunjukkan Surat Pemberitahuan DPTB (Model.A.5-KPU) kepada PPS/KPPS yang wilayahnya membawahi TPS tujuan dimana pemilih yang bersangkutan akan menggunakan haknya untuk memilih di TPS lain. PPS/KPPS mencatat pemilih yang bersangkutan dalam DPTB (Model A.4-KPU). Pemilih tambahan dapat langsung kepada KPPS pada hari/tanggal pemungutan suara, dengan menunjukkan Surat Pemberitahuan DPTB (Model A.5_KPU) dan KPPS mencatat nama pemilih dalam DPTB. Dalam hal pada suatu TPS terdapat pemilih tambahan, KPPS mencatat dalam DPTB (Model A.4-KPU) dan melaporkan kepada KPU Kabupaten Enrekang melalui PPS/PPK.

\section{Pelaksanaan Rekapitulasi Daftar Pemilih Tetap}

KPU Kabupaten Enrekang melakukan rekapitulasi DPT di Kabupaten Enrekang. KPU Provinsi melakukan rekapitulasi DPT di Provinsi. KPU melakukan rekapitulasi DPT secara nasional. Bawaslu, Panwaslu Provinsi, Panwaslu Kabupaten Enrekang, Panwaslu Kecamatan dan Pengawas Pemiliu Lapangan melakukan pengawasan atas pelaksanaan pemutakhiran data pemilih, penyusunan dan pengumuman DPS, perbaikan dan pengumuman DPSHP, penetapan dan pengumuman DPT, DPTB dan rekapitulasi DPT dilaksanakan KPU, KPU Provinsi, KPU Kabupaten Enrekang, PPK, PPS. Data yang diterima oleh Komisi Pemilihan Umum Kabupaten/Kota adalah data pemilih yang berasal dari pemerintah daerah di wilayahnya masing-masing dalam bentuk Data Penduduk Pemilih Potensial Pemilu (DP4). Penyerahan data pemilih tersebut berdasarkan per desa atau kelurahan, sedangkan Komisi Pemilihan Umum menyebutkan berdasarkan pengelompokkan per-Panitia Pemungutan Suara (PPS).

Data Pemilih tersebut digunakan sebagai database kependudukan. Berbeda dengan penyelenggaraan Pemilu di masa Orde Baru menganut periodicregistration system, yang menurut Stephen K.Bailey dan kawan-kawannya (Haryanto, 1984:93) bahwa pemilih harus melakukan pendaftaran pemilih sebelum memberikan suaranya, ada dua system yang dapat digunakan yakni sistem pendaftaran pemilih yang bersifat permanen dan pendaftaran yang bersifat periodik. Setelah Pemilu tahun 2009 dengan dilakukan Pendataan Penduduk dan Pendaftaran Pemilih Berkelanjutan (P4B), Indonesia sudah memiliki data penduduk dan pemilih yang kemudian disebut dengan Data Penduduk Pemilih Potensial Pemilu (DP4). DP4 yang diterima KPU Kabupaten/Kota, kemudian KPU Kabupaten/Kota melakukan pemutakhiran data pemilih, sedangkan data penduduk menjadi tugas pemerintah daerah melalui dinas atau kantor teknis yang memilikinya. Sumber data yang dugunakan oleh KPU Kabupaten/Kota adalah data pemilih berdasarkan data kependudukan, sebagaimana diatur dalam Pasal 10 Undang-Undang Nomor I5 Tahun 20II tentang Penyelenggara Pemilihan Umum pada ayat I(satu) huruf $f$ Undang-Undang Nomor II Tahun 2015 tersebut yang menjelaskan bahwa : memutakhirkan data pemilih berdasarkan data kependudukan dan menetapkan data pemilih sebagai daftar pemilih.

Dari data Penduduk Pemilih Potensial Pemilu (DP4) yang kemudian oleh KPU Kabupaten dan Kota untuk dipilih dan dikelompokkan berdasarkan domisili setiap masyarakat yang memiliki kesamaan 
alamat dalam satu desa atau kelurahan. Apabila sudah selesai dilakukan pengelompokkan, baru dapat ditetapkan menjadi DPS. Data yang dapat digunakan untuk dimutakhirkan (up date) menjadi DPS yang dilakukan oleh PPS setiap desa atau kelurahan. Diperlukan pengetahuan PPS yang memadai dalam melakukan pemutakhiran DPS, apabila DPS yang digunakan tidak akurat, termasuk melakukan pemutakhiran sesuai dengan langkahlangkah yang sudah ditentukan. Kolom pertama dalam DPS harus diisi, baik itu nomor TPS-nya maupun keterangan lain, seperti meninggal, pindah, dan menjadi anggota TNI/Polri. Bagi PPS yang tidak mencantumkan dan tanpa menulis keterangan apapun, pada kolom keterangan, maka sudah ada kekeliruan dalam melakukan pemutakhiran. Ini menunjukkan pengetahuan PPS belum memadai dalam melakukan pemutakhiran DPS. Secara teknis, apabila pemilih baru yang tidak terdaftar dalam DPS dapat dilakukan pengisian pada formulir Model A.AKPU (pemilih baru). Untuk menyelesaikan calon pemilih yang belum terdaftar sebagai pemilih pada saat penyelenggaraan Pemilu Anggota Dewan Perwakilan Rakyat, Dewan Perwakilan Daerah dan Dewan Perwakilan Rakyat Daerah yang disebut sebagai pemilih baru. Penggolongan calon pemilih baru tersebut dapat digolongkan menjadi tiga golongan calon pemilih baru: (I) calon pemilih yang sudah memiliki hak memilih tetapi tidak terdaftar selama beberapa kali Pemilu baru sekarang baru terdaftar sebagai calon pemilih; (2) calon pemilih pada saat yang lalu belum memiliki hak pilih, baik disebabkan oleh belum mencapai usia memilih maupun anggota TNI/Polri yang memasuki masa purna bakti, termasuk calon pemilih yang belum memasuki usia memilih; (3) calon pemilih pada waktu yang lalu terdaftar sebagai pemilih dan menggunakan hak pilihnya, kemudian sekarang tidak terdaftar sebagai pemilih, dianggap sebagai pemilih baru.

Kolom DPS tidak tersedia untuk mencantumkan nama orang yang tidak terdaftar sebagai pemilih, tetapi dapat menggunakan formulir Model A.A-KPU (data pemilih baru) dan menggunakan formulir Model A.2-KPU (Daftar Pemilih Sementara Hasil Perbaikan). Apabila orang yang tidak terdaftar dalam DPS tidak dapat dituliskan Nomor Induk Kependudukan tetapi dapat dicantumkan nama lengkap, tempat tanggal lahir, umur, status perkawinan, dan alamat dalam pemilih baru. PPS dapat mengisi dalam formulir Model A.2-KPU (Daftar Pemilih Sementara Hasil Perbaikan) sebagaimana yang dilakukan, bilamana terdapat kekeliruan dalam pengisian DPS untuk diperbaiki oleh PPS. DPS yang diterima oleh PPS terdapat beberapa kelemahan diantaranya adalah calon pemilih yang tidak terdaftar sebagai calon pemilih dan calon pemilih yang terdaftar akan tetapi terjadi kekeliruan identitas. Pemutakhiran dilakukan berkaitan dengan penambahan jumlah calon pemilih dan memperbaiki identitas calon pemilih. Keakuratan PPS dalam melakukan pemutakhiran sangat tergantung pada PPS melaksanakan kebijakan yang sudah ditetapkan oleh KPU. Kebijakan yang dibuat sebagai arah bagi PPS dalam melakukan pemutakhiran agar mungkin dapat dipenuhi oleh PPS disebabkan tercantum dalam DPS. Persoalan yang paling fital adalah menjaga tingkat kredibilitas penyelenggara Pemilu dengan kesesuaian antara jumlah suara sah dan suara tidak sah, sebanding dengan DPT. Kesesuaian jumlah pemilih berdasarkan DPT dapat menentukan seluruh persoalan suara calon Anggota Dewan Perwakilan Rakyat, Dewan Perwakilan Daerah dan Dewan Perwakilan Rakyat Daerah di tambah dengan jumlah suara tidak sah. Calon pemilih yang namanya tidak tercantum dalam DPS akan tetapi tidak sama antara identitas sebenarnya maka akan menjadi persoalan baru, karena identitas pemilih yang terdapat dalam DPT berbeda dengan identitas pada kartu pemilih atau identitas lain. Disamping identitas calon pemilih dalam DPS yang keliru, juga dipengaruhi oleh kekeliruan dalam melakukan entry data, sehingga terjadi identitas ganda untuk calon pemilih. Tujuan kartu pemilih atau identitas lain seperti Kartu Tanda Penduduk adalah mencocokkan antara identitas calon pemilih dengan DPT supaya tidak terjadi pemberian suara yang berulang-ulang di TPS yang berbeda.

Dampak negatif yang ditimbulkan dari identitas ganda tersebut, dianggap sebagai tindak pidana Pemilu Anggota Dewan Perwakilan Rakyat, Dewan Perwakilan Daerah dan Dewan Perwakilan Rakyat Daerah sebagaimana diatur dalam Undang-Undang Republik Indonesia Nomor 8 Tahun 2012 tentang Pemilihan Umum Anggota Dewan Perwakilan Rakyat, Dewan Perwakilan Daerah dan Dewan Perwakilan Rakyat Daerah $\mathrm{Hal}$ ini sebagaimana diatur pada Pasal 310 Setiap orang yang pada waktu pemungutan suara dengan sengaja memberikan suaranya lebih dari satu kali di satu atau lebih TPS, diancam dengan pidana penjara paling lama I (satu) tahun 6 (enam) bulan dan/atau denda paling banyak Rp.18.000.000,00 (Delapan Belas Juta Rupiah). Daftar pemilih ganda jarang terjadi di TPS yang sama, malah sebaliknya pada warga masyarakat yang tidak memiliki hak pemilih untuk memilih disebabkan tidak masuk dalam DPT. Pemilih yang termasuk dalam daftar pemilih ganda yang berada di TPS yang berbeda, akibatnya tidak menutup kemungkinan akan terjadi penggunaan hak memilih melebihi sebagaimana Undang-Undang Nomor 8 Tahun 2012 Pasal 3I0. Bila ini yang terjadi, maka akan mempengaruhi perolehan suara bagi calon Anggota Dewan Perwakilan Rakyat, Dewan Perwakilan Daerah dan Dewan Perwakilan Rakyat Daerah Kabupaten Enrekang.

Pemilih ganda atau pemilih yang terdaftar sebagai pemilih lebih dari satu nama, baik di TPS yang sama maupun di TPS yang berbeda. Pemilih 
ganda ini akan memiliki hak suara ganda, akibatnya dari terdaftar sebagai pemilih ganda, seorang pemilih akan menentukan pilihannya lebih dari satu kali menggunakan hak pilihnya. Pemilih ganda tersebut akan dikenai ketentuan pidana sebagaimana yang sudah ditentukan. Pemilih ganda juga dapat mempengaruhi perolehan suara bagi pasangan calon tertentu, karena itu memberikan keuntungan secara langsung kepada pasangan calon yang dipilihnya. PPS sebagai bagian dari penyelenggara Pemilu dapat melakukan berbagai upaya untuk mengurangi pemilih ganda, dimulai dari DPS, DPSHP, DPSHP Akhir dan sampai pada penetapan DPT. Mekanisme untuk mengurangi tingkat pemilih ganda menurut Ibrahim (2008:46) rancangan pengembangan standar waktu bagi penyelesaian keluhan tersebut, dan ini perlu dinilai secara terus-menerus validitas dan reabilitasnya. Penilaian secara kontinyu dalam melakukan perbaikan penyedian DPT yang akurat menjadi pekerjaan yang utama bagi PPS meskipun sangat berat dilakukan, karena berkaitan dengan persoalan yang memberikan kesempatan pada setiap pemilih untuk memberikan suaranya.

Daftar pemilih yang tersedia dalam bentuk DPS sharusnya mendapat respon dari masyarakat sebelum DPS ditetapkan menjadi DPT. Bentuk respon akan muncul bermacam-macam dalam memberikan tanggapan perbaikan dan penyempurnaan dari DPS sebelumnya. Daftar pemilih perbaikan dapat disempurnakan menjadi DPT dari sebelum dapat saja memperbaiki DPS yang sudah ada maupun menambah jumlah pemilih yang tidak terdaftar dalam DPS. Secara umum DPS tidak dalam bentuk sempurna, karena itu perlu dilakukan perbaikan yang disebabkan oleh kekeliruan yang tidak disengaja maupun sengaja dilakukan. Daftar pemilih sangat berpengaruh bagi perolehan suara untuk setiap Anggota Dewan Perwakilan Rakyat, Dewan Perwakilan Daerah dan Dewan Perwakilan Rakyat Daerah Kabupaten Enrekang. Kualitas DP4 tidak serta merta digunakan sebagai DPS, tetapi harus diuji kebenarannya. Cara yang ditempuh melalui rekapitulasi jumlah pemilih berdasarkan jenis kelamin dan pengambilan sampel dari beberapa orang berdasarkan domisili untuk menguji tingkat akurasi data pemilih sebelum ditetapkan menjadi DPS. Menghadapi kendala yang terjadinya biasanya daftar pemilih ganda atau calon pemilih didaftarkan sebagai calon pemilih lebih dari satu kali. Kemampuan PPS dalam melakukan pengolahan DPS agar tidak terjadi daftar pemilih ganda pada saat ditetapkan menjadi DPT.

Ketelitian dan kemampuan untuk menggunakan metode perbandingan daftar pemilih sebelumnya, misalnya dengan membandingkan daftar pemilih pada Pemilihan Gubernur dan wakil Gubernur Provinsi Sulawesi Selatan Tahun 2013. Cara membandingkan daftar pemilih sebelumnya dengan DPS diterima oleh PPS menjadi sarana untuk mengeliminir daftar pemilih ganda. Selain cara-cara yang sudah ditentukan dalam Peraturan Komisi Pemilihan Umum Nomor 09 Tahun 2013 yang menjadi pedoman PPS untuk melakukan pemutakhiran DPS. Upaya yang ditempuh oleh PPS agar daftar pemilih lebih mendekati tingkat akurasi yang tinggi, maka saran atau masukan berbagai pihak sangat membantu pada saat pemutakhiran dan pengumuman DPS oleh PPS. PPS melakukan pemutakhiran DPS harus bekerjasama dengan komponen yang lainnya, terutama pengurus RT sebagai pihak yang mengetahui secara persis tentang warga masyarakat. Bantuan teknis maupun non teknis sangat dibutuhkan oleh PPS dalam pemutakhiran DPS, memberikan saran atau masukan, dan melaporkan kepada PPS apabila ada warga masyarakat yang memiliki hak pilih tetapi tidak terdaftar sebagai calon pemilih. Penilaian secara kontinyu dalam melakukan perbaikan penyedian DPT yang akurat menjadi pekerjaan yang utama bagi PPS meskipun sangat berat dilakukan, karena berkaitan dengan persoalan yang memberikan kesempatan pada setiap untuk memberikan suaranya.

Penerapan permanent system oleh petugas PPS tidak akan melakukan pendataan dan mendatangi rumah warga masyarakat dari pintu ke pintu, melainkan hanya keaktifan setiap warga masyarakat untuk terlibat secara langsung. PPS hanya mengumumkan DPS yang sudah diterimanya, kemudian menyampaikan kepada masyarakat secara luas di tempat-tempat yang dianggap strategis. Dalam melakukan pengumuman PPS sudah mengetahui tempat-tempat mudah diakses oleh warga masyarakat atau tempat-tempat yang memungkinkan orang dapat mengetahuinya. Kegiatan mengumumkan DPS sebagai bentuk kegiatan pemutakhiran DPS sejak DPS diterima oleh PPS, Pemutakhiran yang dilakukan oleh PPS adalah DPS, bukan DP4 karena yang menerima DP4 adalah KPU Kabupaten Enrekang yang kemudian ditetapkan menjadi DPS. Bentuk partisipasi masyarakat dalam pemutakhiran daftar pemilih adalah terlibat secara aktif, baik yang sudah terdaftar sebagai pemilih. Kewajiban setiap calon pemilih mendatangi tempat pengumuman DPS untuk mengetahui kepastian dirinya sudah terdaftar atau belum terdaftar sebagai calon pemilih. Bagi yang belum terdaftar sebagai pemilih untuk aktif mendaftarkan dirinya sesuai dengan batas waktu yang sudah ditentukan.

DPS yang diterima oleh PPS terdiri atas dua yakni (I) digunakan sebagai sarana untuk pemutakhiran daftar pemilih, dan (2) digunakan sebagai sarana pengumuman kepada masyarakat. Daftar Pemilih Sementara yang sudah dimiliki oleh Panitia Pemungutan Suara (PPS) menjadi sangat penting untuk diumumkan dan disampaikan kepada masyarakat luas, agar setiap warga masyarakat untuk memperoleh informasi tentang DPS 
disebabkan oleh tata cara mengumumkan dan lokasi pengumuman yang tidak strategis atau kurang tepat. Kemampuan atau kemauan menyampaikan informasi tentang Daftar Pemilih Sementara (DPS) bertujuan mudah diakses oleh calon pemilih guna mengetahui, apakah dirinya terdaftar atau tidak. Minimnya informasi yang disampaikan oleh penyelenggara Pemilu Anggota DPR, DPD dan DPRD untuk menghimbau warga masyarakat melihat DPS, menjadi salah satu sebab warga masyarakat tidak mendatangi tempat yang sudah ditentukan sebagai lokasi pengumuman DPS. Sebelum DPS diumumkan ditempat-tempat yang sudah ditentukan oleh PPS. KPU Kabupaten Enrekang sebagai bagian penyelenggara Pemilu terlebih dahulu menyampaikan informasi berkaitan dengan tempat-tempat yang dapat didatangi oleh warga masyarakat. Informasi dapat disampaikan melalui media massa, guna untuk mengetahui calon pemilih sudah terdaftar atau belum terdaftar dalam Pemilu tersebut.

Tingkat dinamika perubahan daftar pemilih tidak hanya menyangkut perubahan yang terjadi secara umum, seperti perubahan data kependudukan yang dipengaruhi oleh indikator kelahiran, kematian, dan perpindahan. Perubahan data kependudukan yang lebih lambat dibandingkan dengan data pemilih, karena itu database kependudukan tetap digunakan sebagai referensi tersedianya DP4. Data penduduk harus menyesuaikan perubahan data pemilih agar dapat digunakan dalam setiap penyelenggaraan Pemilu.

Penggunaan permanent system yang dianut dalam penyediaan data dan daftar pemilih memungkinkan untuk melakukan pemutakhiran data dan daftar pemilih secara terus-menerus yang dilakukan oleh berbagai pihak. Data pemilih harus dimutakhirkan oleh Pemerintah Daerah oleh Dinas Kependudukan dan Catatan Sipil Kabupaten Enrekang, sedangkan daftar pemilih harus dimutakhirkan oleh KPU Kabupaten Enrekang. Ada beberapa faktor yang menjadi penyebab calon pemilih tidak terdaftar sebagai pemilih: (I)pemilih baru atau baru pindah di tempat yang sekarang sebanyak 33,33 \% ( 7 orang) tidak terdaftar sebagai calon pemilih, sementara di tempat domisili sebelumnya yang bersangkutan terdaftar sebagai pemilih; (2) pemilih tidak terdaftar dalam DPS disebabkan oleh pemilih sebelumnya tidak terdata dan sekarang juga tidak terdata dalam DPS sebagai calon pemilih sebanyak $23,81 \%$ ( 5 orang); (3), pemilih sebelumnya sudah terdata, tetapi sekarang tidak terdata sebagai pemilih sebanyak $28,57 \%$ (6 orang), akibatnya pemilih tersebut tidak terdaftar dalam DPS; dan(4) pemilih baru atau pemilih pemula sebanyak $14,29 \%$ (3 orang) yang tidak terdata dalam DPS.

\section{KESIMPULAN}

Berdasarkan hasil kajian dan analisis fokus penelitian implemntansi kabijakan penyusunan daftar pemilihpada Pemilihan Umum Tahun 2014 di Kabupaten Enrekang, maka dapat dirumuskan beberapa point kesimpulan sebagai berikut :

I. Keberhasilan implementasi kebijakanakan ditentukan oleh beberapa faktor, dan masingmasing faktor tersebut saling berhubunga nsatu sama lain. Dengan adanya Implementasi Kebijakan mengorganisasikan, melaksanakan tugas dan yang menjadi kewenangan dan tanggungjawab KPU Kabupaten Enrekang, khususnya pada Pelaksanaan Pemilihan Umum Tahun 2014. Salah satu yang mejadi fokus kajian dalam penelitian ini adalah implementasi kebijakan penyusunan daftar pemilih dengan menggunakan pendekatan teori Edwar III sebagai pisau analisis untuk membedah fenomena yang diasumsikan sementara sebagai penyebab tidak akuratnya data pemilih di Kabupaten Enrekang, yaitu: dimensi komunikasi; dimensi sumber daya; dimensisi aparatur; dan dimensi struktur birokrasi. Berdasarkan hasil wawancara peneliti dengan beberapa informan, yaitu: Ketua KPU; Sekretaris; Kepala Devisi Data dan Informasi; Anggota PPS dan Anggota Pantarlih terkait dengan peran dan fungsinya sebagai aktor-aktor yang terlibat dalam proses penyelenggaraan Pemillihan Umum sebagaimana yang disebutkan oleh Grindle tentang teori implementasi kebijkan yang memuat dua dimensi, yaitu: isi kebijakan dan konteks kebijakan. Oleh karena itu dapat diungkapkan hasil, yaitu: (I) Pada dimensi implementasi kebijakan, lembaga KPU Kabupaten Enrekang telah melaksanakan atau menerapkan dimensi-dimensi teori implementasi kebijakan Edwar III dalam konteks penyusunan daftar pemilih pada Pemilu tahun 2014 di Kabupaten Enrekang. Hal ini dibuktika ndengan nilai persentase secara kumulatif sebanyak 87,78\%; (2) Pada dimensi Penyusunan Daftar Pemilih, lembaga KPU Kabupaten Enrekang telah melaksanakan kegiatan tersebut secara proporsional, efektif, dan rasional berdasarkan tahapan-tahapan dan dimensidimensi yang menjadi entry point dalam kebijakan penyusunan daftar pemilih tersebut dan tentunya mengedepankan asas legalitas berdasarkan peraturan perundang-undangan yang berlaku. Sejalan dengan hasil peneltian tersebut, maka peneliti mengkonstatir perspektif Riant Nugroho (2004:163)sebagai teori yang mendukung hasil penelitian bahwa implementasi kebijakan dilaksanakan dalam konsekuensi manajemen implementasi kebijakan yang di kelola dalam tugastugas : (I) kebijakan dapat langsung dilaksanakan dengan membangun komunikasi dalam konteks koordinasi yang efektif; (2) Pemanfaatan sumberdaya manusia, ketercukupan anggaran, dandukungan sarana dan prasarana yang memadai; (3)menyesuaikan struktur, menggunakan prosedur, dan pembagian pekerjaan pasilitas organisasi untuk pembentukan sikap dan perilaku individu dengan 
etos kerja yang tinggi; dan (4) menyesuaikan struktur birokrasi, menggunakan prosedur, dan pembagian pekerjaan

2. Faktor-faktor determinan yang menentukan efektivitas implementasi kebijakan penyusunan daftar pemilih pada Pemilu tahun 2014 di Kabupaten Enrekang, yaitu: (a) Faktor internal adalah Kepemipimpinan; dan motivasi; dan (b) Faktor eksternal adalah partisipasi masyarakat.

\section{DAFTAR PUSTAKA}

[I] Amstrong, Mischael, 1999, manajemen sumber daya manusia terjemahan Sofyan dan Haryanto, PT Elex Media Komputindo, Jakarta.

[2] Arep, Ishak, Henri Tanjung, 2003, manajemen sumber daya manusia, Universitas Trisakti, Jakarta.

[3] Gibson, Ivancevich, Donnely, 1994, organisasi dan manajemen perilaku, struktur, proses, Erlangga, Jakarta.

[4] Heidrajman, dan Saud Husnan, 2003, manajemen personalia, BPFE, Yogyakarta.

[5] Nyoman, 20I0, sosiologi pemerintahan, dari perspektif pelayanan, pemberdayaan, iteraksi, dan sistem kepemimpinan Indonesia, Ghalia Indonesia, Bogor.

[6] Jamaluddin Ahmad, 2015, metode penelitian administrasi publik, Gava Media, Yogyakarta.

[7] Kamaruddin Sellang, 2016, administrasi dan pelayanan publik, Penerbit Ombak, Yogyakarta.

[8] Kartini Kartono, 2014, pemimpin dan kepemimpinan, PT. RajaGrafindo, Jakarta.

[9] Mustafa Hasbar, 2014, menguak perilaku organisasi, Penerbit Ombak, Yogyakarta.

[10]Nasir, 2005, metode penelitian, Ghalia Indonesia, Jakarta.

[II]Redi Panuju, 200I, komunikasi organisasi dan konseptual teori ke empirik, Pustaka Pelajar, Yogyakarta.

[12]Rivai Vethzal, 2004, manajemen sumber daya manusia untuk perusahaan, PT. Raja Grafindo, Jakarta.
[13] Simammora, 2004, manajemen sumber daya manusia, STIE YKPN Yogyakarta.

[14]Sthepen P Robbin, 1999, perilaku organisasi konsep, kontroversi, dan aplikasi,Prenhalindo, Jakarta.

[15]Soehartono, 2004, pengaruh gaya kepemimpinan, motivasi, dan kemampuan kerja terhadap kinerja pegawai sekertaris daerah kabupaten Rembang, Universitas Diponegoro, Semarang.

[16]Sondang P. Siagian, 1998, teori aplikasi motivasi dan aplikasinya, Bina Aksara, Jakarta.

[17]Sugiyono, 2005, metode penelitian bisnis, CV. Alfabeta, Bandung.

[18] , 2015, metode penelitian kombinasi, CV. Alfabeta, Bandung.

[19]Sumadi Suryabarata, 1997, kinerja pelaku pendidikan, Liberty, Yogyakarta.

[20] Suparman, 1997, pengelolaan sumber daya manusia, Bumi Aksara, Jakarta.

[21]Thoha, 1999, kepemimpinan dalam manajemen suatu pendekatan perilaku, Raja Grafindo, Jakarta.

[22] Timple A., 2000, manajemen sumber daya kepemimpinan, PT. Elex Media Komputindo, Jakarta.

[23]Mangkunegara,Anwar Prabu.2002 manajemen sumber daya manusia. Remaja Rosdakarya, Bandung.

[24]Luthans, F 2005. Organizational Behavior. New Yoek;McGrawhill.

[25] Mathis, R.L \& J.H Jackson. 2006, human resounce manajement ;manajemen sumber daya manusia, Terjemahan Dian Angelia Jakarta;Salemba Empat.

[26]Nurlaila, 20I0, manajemen sumber daya manusia I, penerbit Lepkhair.

[27]Zainuddin Samad, 2016, birokrasi dalam pelayanan publik, Penerbit Ombak, Yogyakarta. 